\title{
Expert contributions enhance knowledge of valvular heart disease
}

Vinay Badhwar, MD, ${ }^{a}$ Craig R. Smith, $\mathrm{MD},{ }^{\mathrm{b}}$ and Joseph Woo, $\mathrm{MD}^{\mathrm{c}}$

The American Association for Thoracic Surgery family of journals are among the leading scientific publications for the specialty of cardiothoracic surgery. Published in late 2020 and early 2021, 16 invited expert contributions in the field of valvular heart disease will appear in the Journal of Thoracic and Cardiovascular Surgery (JTCVS), JTCVS Techniques, and JTCVS Open. These important peerreviewed selections will summarize important innovations in the areas of aortic valve replacement, aortic valve repair, and the surgical and transcatheter management of mitral and tricuspid valve disease.

The map of clinical decision-making for aortic valve stenosis has been redrawn by transcatheter aortic valve replacement (TAVR). Patients of increased risk and complexity are now routinely managed by TAVR, and the role of surgical aortic valve replacement (SAVR) is being refocused. ${ }^{1-4}$ Some have advocated for a TAVR-first strategy for all, but clinical equipoise remains for many patients of varying anatomy and risk profile. Five-year evidence is emerging to suggest that for patients of lower risk, SAVR may be superior to TAVR in this specific patient cohort. Controversy also exists regarding the management of patients with bicuspid valve disease and for those with anatomic features that may be predictive of worse outcome and paravalvular leak following TAVR. ${ }^{4}$ Contributions in JTCVS and JTCVS Techniques will highlight the merits of redo SAVR, ${ }^{1}$ options for reoperative treatment following failed TAVR/SAVR, ${ }^{2,3}$ and the introduction of a new technique of robotic SAVR, or RAVR. ${ }^{4}$

Aortic valve repair for patients with primary degenerative pathology and insufficiency has existed for decades. However, there are emerging techniques that may facilitate primary valve repair without root-remodeling techniques. Upcoming contributions in JTCVS Techniques will highlight cusp repair, reimplantation valve-sparing root repair, and new insights and alternatives available to manage both tricuspid and bicuspid insufficiency. ${ }^{5-10}$ Furthermore,

From the a Department of Cardiovascular and Thoracic Surgery, West Virginia University, Morgantown, WVa; ${ }^{\mathrm{b}}$ Department of Surgery, Columbia University, New York, NY; and ${ }^{\mathrm{c}}$ Department of Cardiothoracic Surgery, Stanford University School of Medicine, Stanford, Calif.

Received for publication March 8, 2021; accepted for publication March 11, 2021; available ahead of print April 17, 2021.

Address for reprints: Vinay Badhwar, MD, Department of Cardiovascular and Thoracic Surgery, West Virginia University, 1 Medical Center Dr, Morgantown, WV 26506 (E-mail: vinay.badhwar@wvumedicine.org).

J Thorac Cardiovasc Surg 2021;162:86-9

$0022-5223 / \$ 36.00$

Copyright (c) 2021 by The American Association for Thoracic Surgery

https://doi.org/10.1016/j.jtcvs.2021.03.113

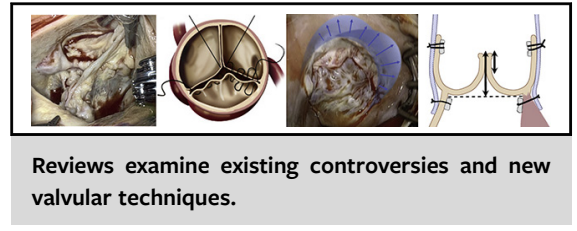

CENTRAL MESSAGE

Expert reviews thoughtfully

explore recent developments in

surgical and transcatheter valve

therapy.

aortic valve repair can even be extended to patients with previous Ross procedures to eliminate pulmonary autograft aneurysms and repair autograft regurgitation from annular and sinotubular dilation. ${ }^{10}$

Finally, the management of mitral and tricuspid disease has continued to evolve with transcatheter innovations. Although surgical management, for now, remains the gold standard, patients of high-to-prohibitive risk will soon have access to transcatheter therapies. For cases of severe mitral annular calcification, left ventricular rupture remains a rare but real concern. ${ }^{11}$ Transcatheter mitral valve replacement is currently undergoing randomized trial investigation with several devices, the majority of which are transapical. ${ }^{12}$ Although the performance of concomitant tricuspid valve repair at the time of left-sided surgery is not without some controversy, increased evidence based clarity is emerging. ${ }^{13}$ For those with severe tricuspid regurgitation without a viable surgical option, transcatheter options are in the early stages of innovation and may one day be available. ${ }^{14-16}$

The JTCVS journals consider Invited Expert Opinions a valuable manner in which to summarize key areas of the literature or present advances in a focused way. The 2021 contributions highlighted aim to inform and inspire future innovative therapies and approaches to valvular heart disease.

\section{Conflict of Interest Statement}

The authors reported no conflicts of interest.

The Journal policy requires editors and reviewers to disclose conflicts of interest and to decline handling or reviewing manuscripts for which they may have a conflict of interest. The editors and reviewers of this article have no conflicts of interest. 


\section{References}

1. Greason KL. Repeat surgical aortic valve replacement: don't stick a fork in it just yet. J Thorac Cardiovasc Surg. March 4, 2021 [Epub ahead of print].

2. Clark A, Malaisrie SC. Failed bioprosthetic valve approaches: transcatheter aortic valve replacement approach. J Thorac Cardiovasc Surg. 2021 [Epub ahead of print].

3. Burke CR, Oyetunji SO, Aldea GS. Surgery after transcatheter aortic valve interventions. J Thorac Cardiovasc Surg Tech. 2021;6:54-8.

4. Badhwar V, Wei LM, Cook CC, Hayanga JWA, Daggubati R, Sengupta PP, et al. Robotic aortic valve replacement. J Thorac Cardiovasc Surg. 2021; 161:1753-9.

5. Zhu Y, Woo YJ. Cusp repair techniques in bicuspid and tricuspid aortic valves. $J$ Thorac Cardiovasc Surg Tech. January 28, 2021 [Epub ahead of print].

6. Svensson LG. The art of aortic valve repair. J Thorac Cardiovasc Surg Tech. January 28, 2021 [Epub ahead of print].

7. David TE. Reimplantation valve sparing aortic root replacement is the most durable approach to facilitate aortic valve repair. J Thorac Cardiovasc Surg Tech. January 27, 2021 [Epub ahead of print].

8. Jahanyar J, el Khoury G, de Kerchove L. Commissural geometry and cusp fusion insights to guide bicuspid aortic valve repair. J Thorac Cardiovasc Surg Tech. 2021 [Epub ahead of print].

9. Federspiel JM, Ehrlich T, Abeln K, Schäfers H. Aortic annuloplasty: subcommissural, intra-annular suture techniques, external and internal rings. J Thorac Cardiovasc Surg Tech. January 28, 2021 [Epub ahead of print].

10. Goldstone AB, Woo YJ. Valve-sparing reoperations for failed pulmonary autografts. J Thorac Cardiovasc Surg Tech. 2021;150:1138-9.

11. David TE. Left ventricular rupture after mitral valve replacement. J Thorac Cardiovasc Surg Open. 2021 [Epub ahead of print].

12. Hong E, Bapat V. Trans-apical implantation of Intrepid device: case planning and operative technique. J Thorac Cardiovasc Surg Tech. 2020;2:27-33.

13. Chikwe J, Megna D. Rationale and surgical strategy for concomitant tricuspid repair. J Thorac Cardiovasc Surg Open. 2020;3:52-61.

14. Chung CJ, George I. Emerging transcatheter therapies for tricuspid valve disease. J Thorac Cardiovasc Surg Open. 2020;2:14-9.

15. Donatelle M, Ailawadi G. Transcatheter tricuspid valve repair: bringing the forgotten valve into the spotlight. J Thorac Cardiovasc Surg. 2020;160: 1467-73.

16. Bapat V, Tang GHL. Emerging transcatheter options for tricuspid regurgitation: many shades of gray. J Thorac Cardiovasc Surg. 2020;160:1460-4.

Key Words: aortic valve repair, aortic valve replacement, transcatheter, mitral, tricuspid 


\section{Valvular Heart Disease: Recent Articles From AATS Journals}
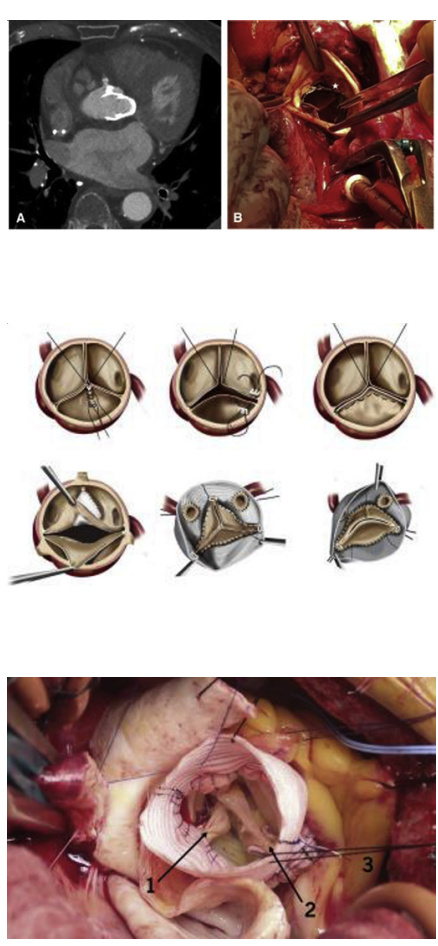

JTCVS TECHNIQUES: The art of aortic valve repair. Svensson LG. J Thorac Cardiovac Surg Tech. 2021 [In press].

Commentary: Getting to the art of the matter with aortic valve repair. Trahanas JM, Chen EP. J Thorac Cardiovasc Surg Tech. 2021 [In press].

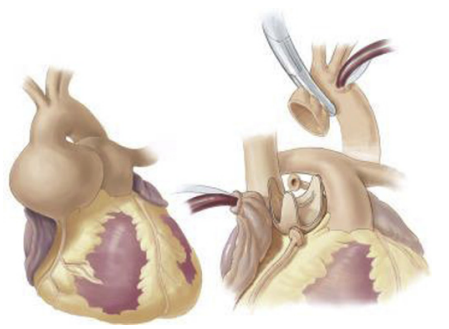

JTCVS TECHNIQUES: Reimplantation valve-sparing aortic root replacement is the most durable approach to facilitate aortic valve repair. David T. J Thorac Cardiovasc Surg Tech. 2021 [In press].

Commentary: Learning from a king. Mobli K, DeAnda A. J Thorac Cardiovasc Surg Tech. 2021 [In press].

Commentary: Learn from the master. Ikonomidis JS. J Thorac Cardiovasc Surg Tech. 2021 [In press].

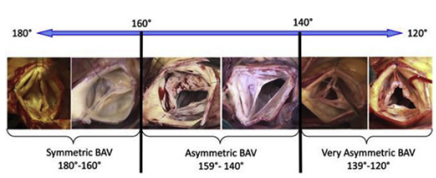

JTCVS TECHNIQUES: Commissural geometry and cusp fusion insights to guide bicuspid aortic valve repair.Jama Jahanyar J, el Khoury G, de Kerchove L. J Thorac Cardiovasc Surg Tech. 2021 [In press].

Commentary: 180-180 repair of bicuspid aortic valve works every time... Except when it doesn't. Mesher AL, Reece TB, Aftab M. J Thorac Cardiovasc Tech. 2021 [In press].

Commentary: Closing the gap on bicuspid aortic valve repair. Mobli K, DeAnda A. J Thorac Cardiovasc Surg Tech. 2021 [In press]. 


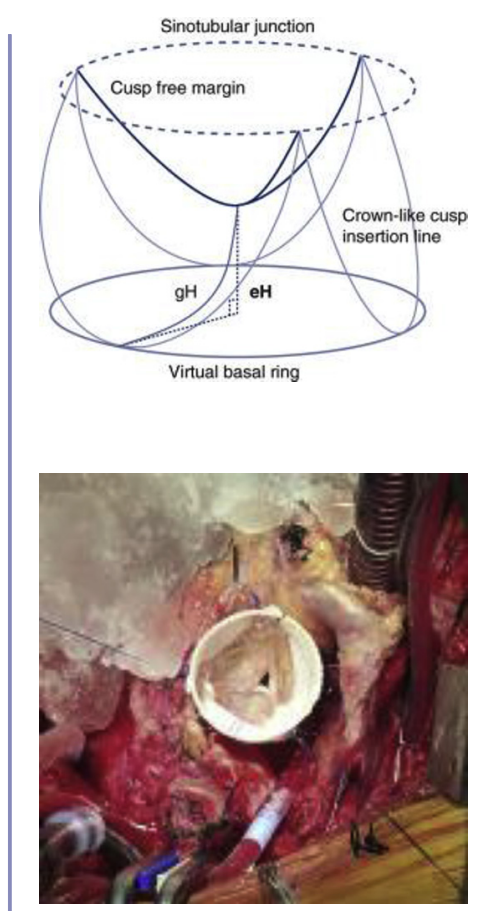

JTCVS TECHNIQUES: Aortic annuloplasty: Subcommissural, intra-annular suture techniques, external and internal rings. Federspiel JM, Ehrlich T, Abeln K, Schäfers HJ. J Thorac Cardiovasc Surg Tech. 2021 [In press].

Commentary: Aortic annuloplasty: One size does not fit all. Ouzounian M, Chu MWA, Peterson MD, El-Hamamsy I, Canadian Thoracic Aortic Collaborative. J Thorac Cardiovasc Surg Tech. 2021 [In press].

Commentary: Aortic valve annuloplasty: The true and the false. Pacini D, Murana G. J Thorac Cardiovasc Surg. 2021 [In press].

Commentary: Suture annuloplasty for isolated aortic valve repair: The Holy Grail is yet to be found. Dagenais F. J Thorac Cardiovasc Surg Tech. 2021 [In press].

JTCVS TECHNIQUES: Valve-sparing reoperations for failed pulmonary autografts.

Goldstone AB, Woo YJ. J Thorac Cardiovasc Surg Tech. 2021 [In press].

Commentary: Valve sparing surgery after the Ross procedure: Keeping the promise alive. El-Hamamsy I. J Thorac Cardiovasc Tech. 2021 [In press].

Commentary: The pulmonary autograft, too valuable to repeal. Al Halees Z. J Thorac Cardiovasc Surg Tech. 2021 [In press].

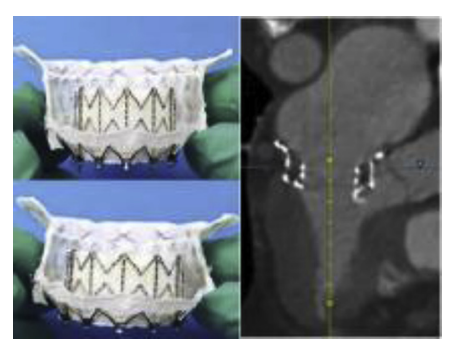

JTCVS TECHNIQUES: Transapical implantation of the Intrepid device: Case planning and operative technique. Hong E, Bapat V. J Thorac Cardiovasc Surg Tech. 2020;2:27-33.

Commentary: Transapical transapical mitral valve replacement: Here to stay or a gateway procedure? Edelman JJ, Kauten J, Thourani VH. J Thorac Cariovasc Surg Tech. 2020;2:34-35.

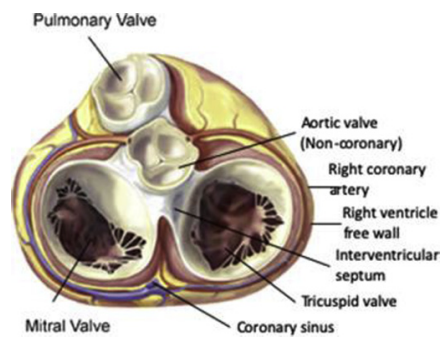

JTCVS OPEN: Rationale and surgical strategy for concomitant tricuspid repair. Chikwe J, Megna D. J Thorac Cardiovasc Surg Open. 2020;3:52-61.

Commentary: Forgotten no more. Hirji SA, Kaneko T. J Thorac Cardiovasc Surg Open. 2020;3: 62-63.

Commentary: Tricuspid repair—why the hesitation? Nafday HB, Grossi EA. J Thorac Cardiovasc Surg Open. 2020;3:64-65. 